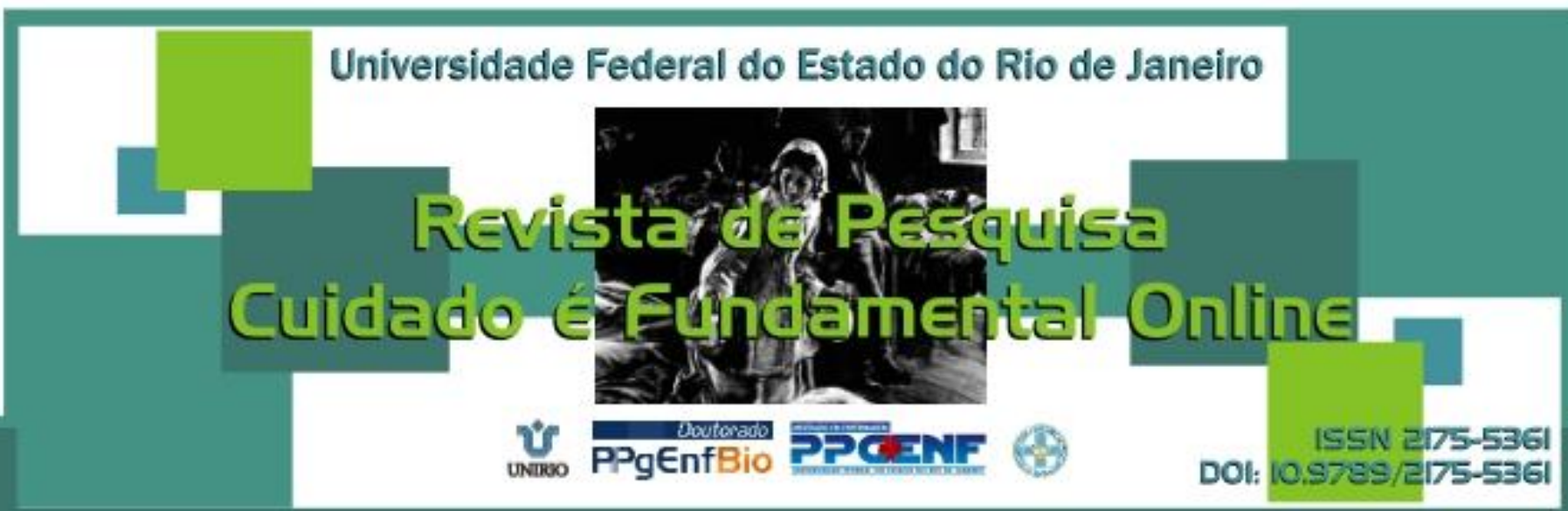

\title{
RESEARCH
}

\section{The care on chemotherapy: the perception of the nursing team}

O cuidar em quimioterapia: a percepção da equipe de enfermagem

La atención en quimioterapia: la percepción del equipo de enfermería

Eliane de Fátima Almeida Lima ${ }^{1}$, Sasha Oliveira Coelho ${ }^{2}$, Franciele Marabotti Costa Leite ${ }^{3}$, Ana Inês Sousa ${ }^{4}$, Cândida Caniçali Primo ${ }^{5}$

$\leftrightarrow$ ABSTRACT

Objective: To knowing the perception of the nursing staff of a unit of chemotherapy about care. Method: A descriptive and qualitative study, performed in a hospital of a general philanthropic and private character in Vitória/Espírito Santo, Brazil. The participants were eight nurses working in the unit. The data were recorded and collected through a semi-structured interview with the following question: What is care for you? Results: For the analysis of information followed the steps recommended for thematic analysis, resulting in structuring the analytical category called: Nursing care in chemotherapy. Conclusion: The results indicate that care requires much more than technical scientific knowledge, it requires understanding of the background of your individuality, from an interpersonal valuation of the human person, therefore contributing with the process of humanization of care. Descriptors: Caring, Oncologic patient, Nursing team.

\begin{abstract}
RESUMO
Objetivo: Conhecer a percepção da equipe de enfermagem de uma unidade de quimioterapia acerca do cuidado. Método: Estudo descritivo, qualitativo, realizado em um hospital de caráter geral filantrópico e privado no município de Vitória/ES, Brasil. Participaram oito profissionais de enfermagem que atuam na unidade. Os dados foram gravados e coletados através de entrevista semi estruturada com a seguinte questão norteadora: o que é cuidar para você? Resultados: Para a análise das informações seguiu-se os passos preconizados para análise temática, resultando na estruturação da categoria analítica denominada: O cuidado de enfermagem em quimioterapia. Conclusão: Os resultados apontam que cuidar exige muito mais do que conhecimentos técnico científicos, requer a compreensão a fundo de sua individualidade, a partir de um relacionamento interpessoal de valorização da pessoa humana, contribuindo, consequentemente, com o processo de humanização do cuidado. Descritores: Cuidar, Paciente oncológico, Equipe de enfermagem
\end{abstract}

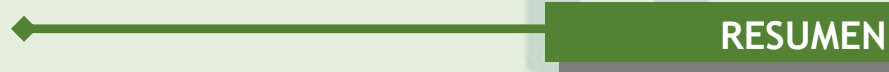

Objetivo: Conocer la percepción del equipo de enfermería de una unidad de quimioterapia en la atención. Método: Estudio descriptivo y cualitativo realizado en un hospital de carácter general filantrópico y privado en Vitória/Espírito Santo, Brasil. Los participantes fueron ocho enfermeros que trabajan en la unidad. Los datos fueron registrados y recolectados a través de entrevista semiestructurada, con la siguiente pregunta: ¿Qué es cuidar para usted? Resultado: Para el análisis de las informaciones siguió se los pasos recomendados para el análisis temático, lo que resultó en la estructuración de la categoría analítica llamada: Cuidados de enfermería en la quimioterapia. Conclusión: Los resultados indican que la atención requiere mucho más que el conocimiento técnico científico, requiere un profundo conocimiento de su individualidad, a partir de una valoración interpersonal de la persona humana, por lo tanto, ayudar con el proceso de humanización de la atención. Descriptores: El Cuidado, Paciente Oncológico, Equipo de enfermería.

${ }^{1} \mathrm{PhD}$ in Nursing. Master in Nursing. Professor of Graduate Nursing, Federal University of Espírito Santo, Vitória (ES), Brazil. Researcher for CNPq - CARE: Teaching and Research in Nursing E-mail: elianelima66@gmail.com. ${ }^{2}$ Nurse, graduated from the Federal University of Espírito Santo, Vitória (ES), Brazil. email: yesinha@hotmail.com. ${ }^{3} \mathrm{PhD}$ in Epidemiology. Master in Public Health. Professor of Graduate and Professional Master in Nursing, Federal University of Espírito Santo, Vitória (ES), Brazil. Researcher for CNPq - CARE: Teaching and Research in Nursing E-mail: francielemarabotti@gmail.com. ${ }^{4} \mathrm{PhD}$ from the National School of Public Health / Oswaldo Cruz Foundation. Associate Professor, Department of Public Health Nursing, School of Nursing Anna Nery, Federal University of Rio de Janeiro. E-mail: anaines@pr5.ufrj.br. 5 PhD in Nursing. Master in Public Health. Professor of Graduate and Professional Master in Nursing, Federal University of Espírito Santo, Vitória (ES), Brazil. Researcher for CNPq - CARE: Teaching and Research in Nursing E-mail: candidaprimo@gmail.com. 


\section{INTRODUCTION}

$\mathrm{n}$ recent decades, the number of cancer patients has increased significantly, turning cancer into a clear public health problem worldwide. The World Health Organization estimated that in 2030, one can expect 27 million incident cases of cancer, 17 million deaths and 75 million people living annually with cancer. On the other hand, the advancement of science and technology has enabled the improvement of the diagnosis and treatment culminating in curing various diseases, among them cancer, increasing the average life expectancy. ${ }^{1}$

Facing a cancer diagnosis, each person responds individually, and reactions such as fear, anxiety, denial, hopelessness and loss of control are common. In this scenario, the health staff, especially the nurses, who are very closed to them, and for a longer period, the patient and their families must be able to provide a humanized, understanding them and supporting them in all needs, during the disease process. ${ }^{2}$

The cancer treatment can be accomplished by four approaches: surgery and radiotherapy as local treatments; chemotherapy and therapy with biological agents (as hormones, antibodies or growth factors) as treatments systemic. Chemotherapy is a modality important therapeutic for cancer, represented by the employment of substances isolated chemical or in combination. Chemotherapy is associated with physical side effects as nausea, vomiting, anorexia, constipation, diarrhea, fatigue and mucositis these effects along with the onsets own the disease can result the patient to feel powerless to react and fight for survival. ${ }^{3}$

It must be considered in the care of these patients, the impact of the disease and its treatment as an issue that creates pain and suffering being necessary to provide means for people with cancer feel relieved and at the same time may have wanted to express their needs. It is through the bonding and trust that the health care plan proposed by the nurse can be effected. ${ }^{3}$

Nursing care requires presence, flexibility, co-responsibility, sharing of feelings, knowledge and solidarity ${ }^{2}$. Accordingly, care should be directed to the patient, his family and other significant people, contemplating the physical, emotional, and social and spiritual. ${ }^{4}$ Thus, the care of the person with cancer may be dealing with a very complex care. $^{5}$

The performance of nursing staff is essential, considering that caring is a fundamental action for the promotion and restoration of health of cancer patients. Given the above this research aims to understand the perception of the nursing staff of a unit of chemotherapy on the care of the person with cancer.

\section{METHODOLOGY}


This study is characterized as a descriptive and an exploratory research with a qualitative approach, developed in the chemotherapy unit of a private hospital of philanthropic character, in Vitória/Espírito Santo, Brazil. It is a Center of High Complexity in Oncology and attends public patients of SUS and health plans, offers chemotherapy, radiotherapy and offers complementary therapies.

The study population was composed of ten professional nursing staff working in the field of chemotherapy, and the sample consisted of eight professionals, since two refused to participate.

To collect the information recorded interview was used for a digital camera Sony Cyber-shot DSC-S750, using a semi-structured comprising: identifying data of the participants (name, gender, age, time of work in the area oncology, working week, bond with another institution), and the following question: what is to care for you?

The choice of semi-structured interview was the possibility of greater flexibility, depth, repetition and reflection. This type of interview is still a valuable tool to gather descriptive data in the language of the subject, allowing the researcher intuitively develop an idea about the way subjects interpret aspects of the world. ${ }^{6}$

The data collected between November 2011 and were analyzed according to methodological proposal, which comprises: sorting, sorting the data and final analysis, following also the steps recommended for thematic analysis. ${ }^{7}$

The project was approved for its implementation, according to the opinion paragraph $n^{\circ}$. 242/11, of the Committee of Ethics in Research of the Center of Health Sciences of the Federal University of Espírito Santo.

To guarantee the anonymity of respondents, the authors identified the same names with stones: Amethyst, Diamond, Onyx, Pearl, Sapphire, Crystal, Ruby and Emerald.

\section{RESULTS AND DISCUSSION}

Regarding the characteristics of the sample subjects: five are nurses and nursing technicians are three; two males and six females, ages 24-34 years old. The time of action in oncology was 2 months to 6 years, the sector workweek is 44 hours, and all respondents do not work in another institution.

From the research question "What is care for you?". We obtained various responses from the nursing staff, which were subsequently analyzed and grouped in the following analytic category: Nursing care in chemotherapy.

\section{Nursing care in chemotherapy}

The nurses interviewed recognize that caring "is to serve, is offering another form of service as the result of our talents, preparation and choices", these acquired in our experience of caregiver, demonstrating to be careful attitudes coming of our knowledge, affection and skills, which, in the other direction, turn into actions that reflect the human being who we are and how we care for. ${ }^{8}$ As observed in extracts of statements below: 
Caring for me is if you donate to the patient [...] (Pérola)

[...] Then, care is if we donate, be doing a good person [...] (Pérola)

[...] If you donate what you know, to the patient're better off [...] (Rubi)

Besides the perception that care involves giving, caring performed by nursing can be understood as a process that involves and develop actions, attitudes and behaviors that are based on scientific, technical, personal, cultural, social, economic, political and psychospiritual seeking promotion, maintenance and restoration of health or dignity, and human wholeness. ${ }^{9}$ To another author, nursing care is the essence of the profession and belong to two distinct spheres: one objective, which refers to the development of techniques and procedures, and a subjective, based on sensitivity, creativity and intuition. ${ }^{10}$ Thus, we can show that care is the essence of nursing in the following statement:

Caring in nursing is our daily working tool, it is our practice day to day [...] (Rubi)

Assistance to cancer patients offers shows its complexity as it involves multiple aspects such as physical, psychological, social, cultural, family, spiritual and economic, as well as the prejudices and taboos, as the word cancer also comes loaded the idea of the curse and death. ${ }^{11}$ Thus, the professional has to respect the individuality of each patient and perception, because although there similar aspects in daily living with cancer, each facing the disease according to their beliefs, values and ways of seeing the world. 1 the statement below shows the aspects to be included in a complex service:

...care it encompasses other aspects, economic and social aspect, cultural aspect, familiar look [...] (Diamante)

Often, before the cancer diagnosis, the family disrupts your routine and changing dynamics therefore required to be monitored and assisted. ${ }^{12}$ Thus, nursing professionals, who stay longer with the patient and family members also constitute themselves into true links, with the potential to promote the interaction of all involved and seek resources to enable the sick person and his family a better quality of life. ${ }^{5}$

In addition, the family is inserted as an important element in nursing work, since it acts as the impact zone and neutralizing agent between individuals and society, promoting a psychosocial support to their family and also being an important vehicle for transmitting culture, which include health care. It is the nursing staff, to investigate what are the coping strategies that patients and families are using that time to establish a cross-cultural approach that optimally meets your needs, often veiled. ${ }^{13}$ In light of these issues, there is the concern of the nursing staff in the care of extended family, in the following excerpt:

[...] Goes from the more technical issue, even more a matter of social and family [...] (Diamante)

The proper care needs of the patient requires the professional, the ability to perceive and identify the needs of others, and these attributes arise from experience and practice within the practice of nursing. The more accurate is the perception of the more professional can provide care in accordance with the peculiarities and uniqueness of each 
individual. The interaction is the link between the caregiver and the care receiver and allows the first, the perception and identification of the needs of the second. Therefore, the assistance provided by professional nursing aims to accommodate the needs of the patient, expressed or not, because it involves caring meet the needs of the other, perceived by nursing staff, in addition to those reported by the patient at the time of action in care. ${ }^{8}$

Importantly, the good relationship between patients and nursing staff is a difference in the quality of care provided. Thus, the patient with their specificities, their needs, their high or recovery, are the main reason of nursing care, which should therefore be performed efficiently with compromising who develops, ensuring quality of care provided and mainly the satisfaction of patients and their families. ${ }^{14}$

In the account of the majority of respondents, they emphasize care as to assist and meet the needs of the cancer patient demonstrates to nursing staff at the time:

Care is to assist the patient [...] (Ametista)

[...] Look at me is you promote to any person who is, in the case of the patient, promoting him what he needs at that moment, at that specific moment that you are taking care of him [...] (Ônix)

[...] Be aware besides the prescription,'re aware the other needs of the patient, are you heed some discomfort he is feeling, providing guidance ... (Rubi)

Caring is giving me an assist on the patient's needs, personalized assistance [...] (Esmeralda)

Corroborating the above reports, one study showed that adequate interpersonal relationship between nurse and patient allows not only allow for the identification of care needs, but also the clarification of the possible effects and how to manage them, contributing to lower anxiety and increase treatment adherence. We emphasize that, for this, the nurse needs to develop their communication skills and remember that technology becomes important when you do not forget the human aspect and the good relationship between the patient and the service provider is a difference in the quality of care. ${ }^{15}$

We can say therefore that good interpersonal contributes positively in the quality of care delivered, representing a gain for both parties. Another study says, it takes a few more minutes to be with the patient, but if gains in quality of care, representing greater gain for everyone. Reflected that this is the difference between providing quality care, or simply do it by rote. ${ }^{10}$

Providers also perceive caring in a broader sense as a care through "relationship with each other, as an expression of interest and affection". 8 So the care is not limited to performing a procedure, it includes the moral component (of duty without obligation) and emotional, the cognitive perception, knowledge and intuition. This way of understanding the care environment changes, harmonizing relationships, sensitizes the human each and energize our potential to help others find their potential and cope with adversity. ${ }^{1}$

In this context, presuppose a care that focuses on the physical dimensions, psychological and social, so it is possible to perceive the nursing care attitudes in verbal and non-verbal, expressed through talk, touch, with the intent to convey tranquility, warmth, comfort, safety, care and well-being, ie, we need to "realize the imperceptible, the art of perceiving the whole and not just part of it". ${ }^{16}$ 
Therefore, the shape, the way of caring, sensitivity, intuition, the "cause", cooperation, availability, participation, love, interaction, scientific, authenticity, engagement, the bond shared spontaneity, respect, presence, empathy, commitment, understanding, mutual trust, setting limits, the exploitation of the potential, the view of the other as unique, the perception of the existence of the other, the delicate touch, respect for silence, receptivity, observation, communication, warmth and smile, are the essential elements that make a difference in the care provided to cancer patients. ${ }^{9}$

The following sections include how much the team appreciates these aspects included in care:

$[\ldots]$ Is to strengthen the emotional him, he gets upset at first here [...] (Ametista)

[...] Will think a little more emotional than technical assistance [...] (Esmeralda)

Thus, it will take care of the technical assistance from the nurse uses and that the nursing technician uses up a mere conversation locate people within your treatment, what are the possibilities that may occur, so everything to me is caring. (Diamante)

[...] I think care is much more human than the very same practice of nursing [...] (Cristal)

[...] To be close to the patient, gives a good day for this patient, know what this patient needs more medication beyond, beyond curative [...] (Cristal)

Often what he really needs is affection, conversation, a ring, that someone pays attention on him [...] (Ônix)

In addition to all these questions, one has to appreciate that the scientific technical knowledge is essential in nursing care to the patient with cancer, in order to act safely in the face of situations that arise in which you need and be able to act. The careful technical and expressive are not mutually exclusive, but complementary, both important aspects of human care nursing. ${ }^{1}$ In the report that follows highlights the importance of technical and scientific knowledge:

[...] So he needs our support as psychological knowledge of the matter [...] (Pérola)

Agreeing to speak up, a study showed that, in relation to the care process, the interaction professional/patient indicated two factors that influenced the positive evaluation of service quality: the ability of the professional technique, which depends on your knowledge and judgment used in strategic decisions to provide appropriate care to the patient and their competence to implement this process, and the appropriate interpersonal skills, which is vital, because it includes the affability and interest of providers of care for patients with and encouragement so that they decide actively participate in the care and treatment proposed. ${ }^{16}$

Thus, care adds a series of professional actions of the very nature of nursing, which is realized in practice and multidisciplinary theoretical framework supported, even in other sciences. This happens in the process of therapeutic interaction between humans based on empirical knowledge, personal, ethical, aesthetic and political intent to promote the health and dignity of human life in the process. ${ }^{9}$ 
It was noted in the research that caring for chemotherapy nursing staff means donate, watch, be alert, give affection, attention, think about, discuss, establish relationships between professionals and cancer patients, as well as the technical and scientific knowledge is a form of care.

Note on the fragments of interviews that care is complex and needs to be seen as a set that involves physical, emotional, social and spiritual.

A study of this nature allows the reflection of the care provided by the nursing staff requires more than technical and scientific skills, requires understanding the background of your individuality, from an interpersonal valuation of the human person, contributing consequently, the process of humanization of care.

\section{REFERENCES}

1. Fontes CAS, Alvim NAT. A relação humana no cuidado de enfermagem junto ao cliente com câncer submetido à terapêutica antineoplásica. Rev. Acta paul. enferm. [online], 21(1): 77-83, 2008.

2. Bettinelli LA. Cuidado Solidário. 1998. 180f. Tese (Doutorado em Enfermagem: Filosofia, Saúde e Sociedade) - Programa de Pós Graduação em Enfermagem, Universidade Federal de Santa Catarina, Florianópolis.

3. Anjos ACY. A experiência da terapêutica quimioterápica oncológica na visão do paciente. 2005. 127f. Dissertação (Mestrado em Enfermagem Fundamental) - Programa de Pós Graduação em Enfermagem, Escola de Enfermagem de Ribeirão Preto da Universidade de São Paulo, Ribeirão Preto.

4. Stumm EMF, Leite MT, Maschio G. Vivências de uma equipe de enfermagem no cuidado a pacientes com câncer. Cogitare Enfermagem, Paraná, 13(1): 75-82, 2008.

5. Carvalho MVB, Merighi MAB. O cuidar no processo de morrer na percepção de mulheres com câncer: uma atitude fenomenológica. Rev. Latino-Am. Enfermagem [online], 13(6): 951-9, 2005.

6. Bogdan R, Biklen S. Investigação qualitativa em educação: uma introdução à teoria e aos métodos. $2^{\text {a }}$ edição. Porto: Porto Editora, 1994.

7. Minayo MCS. O desafio do conhecimento: pesquisa qualitativa em saúde. $4^{\mathrm{a}}$ edição. São Paulo: Hucitec, 1998.

8. Baggio MA. O Significado do cuidado para profissionais da equipe de enfermagem. Rev. Eletrônica de enf. 8(1): 9-16, 2006.

9. Rocha PK, Prado ML, Wall ML. Cuidado e tecnologia: Aproximação através do modelo de cuidado. Rev. Brasileira de enf. 61(1): 113-6, 2008. 
10. Souza ML, Sartor VVB, Padilha MICS, Prado ML. O Cuidado em Enfermagem: uma aproximação teórica. Rev. Texto contexto - enferm. [online]. 14(2): 266-70, 2005.

11. Costa CA, Filho WDL, Soares NV. Assistência humanizada ao cliente oncológico: reflexões junto à equipe. Rev Bras Enferm. 56(3): 310-4, 2003.

12. Paro D, Paro J, Ferreira DLM. O enfermeiro e o cuidar em Oncologia Pediátrica. Arq Ciênc Saúde. 12(3): 151-7, 2005.

13. Soares LC, Klering ST, Schwartz E. Cuidado transcultural a clientes oncológicos em tratamento quimioterápico e a seus familiares. Rev. Cienc Cuid Saúde. 8(1): 101-8, 2009

14. Barbosa LR. Relações entre qualidade da assistência de enfermagem: revisão integrativa de literatura. Rev Brasileira de Enf. 61(3): 366-70, 2008.

15. Fonseca SM, Gutiérrez MGR, Adami NP. Avaliação da satisfação de pacientes oncológicos com atendimento recebido durante o tratamento antineoplásico ambulatorial. Rev. bras. enferm. [online]. 59(5): 656-60, 2006.

16. Recco DC, Luiz CB, Pinto MH. O cuidado prestado ao paciente portador de doença oncológica: na visão de um grupo de enfermeiras de um hospital de grande porte do interior do estado de São Paulo. Arq Ciênc Saúde. 12(2): 85-90, 2005. 